\title{
SERUM INHIBITORS OF ELASTASE, TRYPSIN, AND PLASMIN IN CHRONIC RHEUMATIC DISEASES
}

\author{
BY \\ W. ARDELT, S. KSIEZNY, IZABELLA NIEDZWIECKA-NAMYSLOWSKA,
AND A. Z. BUDZYNSKI \\ From the Department of Biochemistry, Institute of Rheumatology, Warsaw, \\ and the Department of Radiobiology and Health Protection, \\ Institute of Nuclear Research, Warsaw, Poland
}

There have been few studies of the serum level of proteolytic inhibitors in chronic rheumatic diseases. Patients with rheumatoid arthritis (RA) were found to have an increased level of serum trypsin inhibitor (Coke, 1949; Ragan, Grokoest, and Boots, 1949) as well as of plasmin inhibitor (Thomas and Dingle, 1955; Kopeć and Amatuni, 1961).

Pancreatic elastase is an enzyme with high affinity for some of the protein components of connective tissue, particularly elastin. Disturbances of connective tissue metabolism in chronic rheumatic diseases are of special interest with respect to this specific lytic enzyme system and its inhibitors present in serum. Serum inhibitor of elastase was found in normal human subjects by Balo and Banga (1949). Its level is said to be increased in pregnancy (Walford and Schneider, 1959; Schneider, Walford, and Dignam, 1960; Gilfillan, Sbarra, and Bardwil, 1961) and in cases of the Ehler-Danlos syndrome (Hall, Keech, Reed, Saxl, Tunbridge, and Wood, 1955), but the latter observation was not confirmed by Carter and Walford (1963). Contradictory reports on inhibition of elastolysis by serum of patients suffering from atherosclerosis have also been published (Balo and Banga, 1953; Walford and Schneider, 1959; Balo, 1960; Banga, 1963; Gilfillan and others, 1961). According to Gilfillan and others, (1961) the inhibitor of elastase was increased in certain cases of RA and tuberculosis. Our previous preliminary communication (Ardelt, Niedzwiecka-Namyslowska, Loegler, Ksiezny, and Budzynski, 1966) indicated an increase in the level of inhibitor of the elastolytic function of elastase in both RA and ankylosing spondylitis (AS). No further detailed studies have been made, however, of the inhibiting activity against all three enzymes.

Our present aim was to study the inhibition of the elastolytic and proteolytic functions of elastase by serum of patients suffering from RA and AS, and by serum of normal human subjects. Furthermore in some of the patients, the serum inhibitors ofer trypsin, plasmin, and both of the elastase activitiest were determined in order to study the mutual rela-o tionship between the inhibitors of the various en-을 zymes.

Material
The studies were conducted on patients suffering from㑊
RA and AS, and control sera were obtained from healthy
blood donors.

Stained elastin was used as a substrate for the $\operatorname{deter} \overrightarrow{0}$ mination of the elastolytic function of elastase. Elastong was obtained from ox ligamentum nuchae by the methed? of Partridge, Davis, and Adair (1955). This preparating was stained with orcein (G. T. Gurr, London) accord河g to the method described by Banga (1963). AdditionaP elution of weakly-bound orcein was performed in 0.080 M TRIS-HCL buffer at $p \mathrm{H} 9 \cdot 0$. Stained elastin was drieco at room temperature.

Casein solution for proteolytic determinations was $\overrightarrow{\overrightarrow{0}}$ obtained from light white casein (BDH, England) according to the method of Kunitz as described by Laskowski (1955). This solution was used for determining the proteolytic activity of elastase and trypsin but it appearedo unsatisfactory for determining that of plasmin. Fore this purpose another casein solution was prepared as follows: about 5 per cent. casein solution in $0 \cdot 1 \mathrm{M}$ sodium. phosphate buffer $p \mathrm{H} 7 \cdot 6$ was exhaustively dialyzed against this buffer. Thereafter the solution was diluted with the same buffer to 3 per cent. casein concentration and 0 heated in boiling water bath for 15 minutes.

Elastase was obtained from commercial pancreatino (Fluka, Buchs) according to the method of Bagdy and Banga (1957).

Trypsin was a crystalline preparation (Spofa, Prague)

Plasmin, obtained by streptokinase activation of human plasminogen prepared according to the method of Kline ${ }^{\omega}$ (1953), was kindly supplied by Mr. Z. Wegrzynowicz, Institute of Nuclear Research, Warsaw.

All the other reagents were Polish commercial productso of analytical grades of purity. 
Determination of Inhibitor Activity

Enzyme activity was measured by the amount of the product formed. Determination of the inhibitory effect of the material tested was based on the measurement of the decrease in enzyme activity.

Inhibitor activity was expressed as a percentage of enzyme activity inhibition, using the equation:

$$
\text { Percentage inhibition }=\frac{\mathrm{Ac}-\mathrm{Ai}}{\mathrm{Ac}} \times 100
$$

where Ac and Ai represent enzyme activity without and in the presence of serum, respectively.

Inhibition of the elastolytic function of elastase was determined in the following manner: $0.03 \mathrm{ml}$. of the serum tested and $100 \mu \mathrm{g}$. elastase in $0.8 \mathrm{ml} .0 .08 \mathrm{M}$ TRIS-HCL buffer $p \mathrm{H} 8.6$ were mixed and incubated for $30 \mathrm{~min}$. at $25^{\circ} \mathrm{C}$. Thereafter $30 \mathrm{mg}$. stained elastin was added and the suspension was diluted to $6 \mathrm{ml}$. with the same buffer. Elastolysis was carried out with continuous shaking for $60 \mathrm{~min}$. at $38^{\circ} \mathrm{C}$. The reaction was stopped by filtration of the remaining unsolubilized elastin. The amount of solubilized substrate in filtrate (Ai-value) was calculated from the amount of dye released under enzyme action, determined by spectrophotometry at $570 \mathrm{~m} \mu$. The Ac-value was determined by the same procedure, using $0.03 \mathrm{ml}$. of $0.08 \mathrm{M}$ TRIS-HCL buffer instead of serum. In our experimental conditions, Ac-value was equal to $6.6 \pm 0.1 \mathrm{mg}$. of solubilized elastin.

The amount of serum used for the determination was chosen on the basis of experiments in which the relationship was investigated between the volume of serum added and the percentage of inhibition. The results of these experiments are presented in Fig. 1, which shows a distinct difference between the inhibition of elastolysis by normal and pathological serum at $30 \mu \mathrm{l}$. of the serum

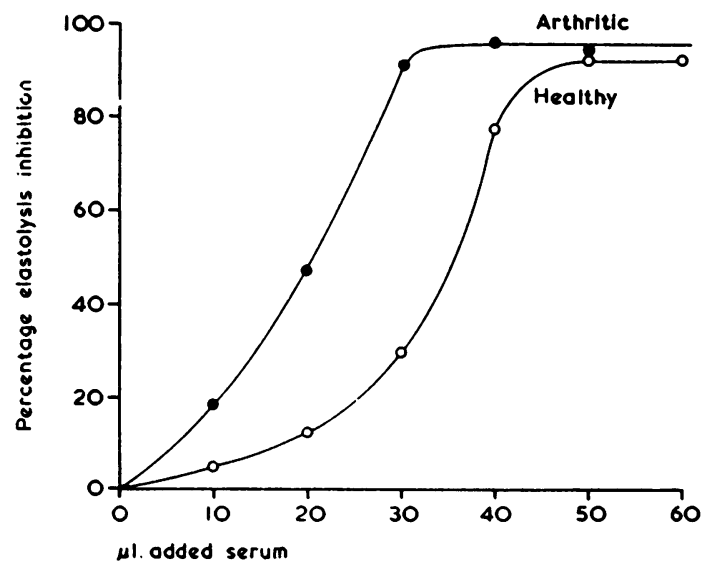

Fig. 1.-Relationship between amount of serum added to elastaseelastin system and percentage of elastolysis inhibition. tested. An attempt was made to estimate the influence of salicylic acid on elastolysis, because many patients were treated with salicylates. It was shown that salicylic acid in the concentration range between $3 \times 10^{-4} \mathrm{M}$ and 1.5 $\times 10^{-3} \mathrm{M}$ inhibits elastolysis to the same extent (about 5 per cent.); the concentration range tested was that of the mean concentration of salicylate in the serum of patients treated with the drug, which amounts to about $1 \times 10^{-3} \mathrm{M}$.

Inhibition of the proteolytic function of elastase was determined as follows: $0.03 \mathrm{ml}$. of diluted serum $1: 10$ with $0.1 \mathrm{M}$ sodium phosphate buffer $p \mathrm{H} 7.6$ and $15 \mu \mathrm{g}$. elastase in $0.97 \mathrm{ml}$. of the same buffer were mixed and incubated for $10 \mathrm{~min}$. at $35^{\circ} \mathrm{C}$. Thereafter $1 \mathrm{ml}$. of 1 per cent. casein solution was added. Proteolysis was carried out for $20 \mathrm{~min}$. at $35^{\circ} \mathrm{C}$. without shaking. The reaction was stopped by addition of $3 \mathrm{ml} .5$ per cent trichloroacetic acid (TCA) and left for over 1 hour at room temperature. The amount of non-precipitable products in supernatant (Ai-value) was determined by Folin's method. The Ac-value determined by the same procedure was equal to $0.90 \pm 0.02 \mathrm{mg}$. of TCA-soluble material. The amount of serum used for the determination was chosen on the basis of a procedure similar to that described for the inhibition of elastolysis. The results of such an experiment are presented in Fig. 2, which shows a sufficient difference between the inhibition of proteolysis by normal and pathological serum at $3.0 \mu 1$. of the serum tested.

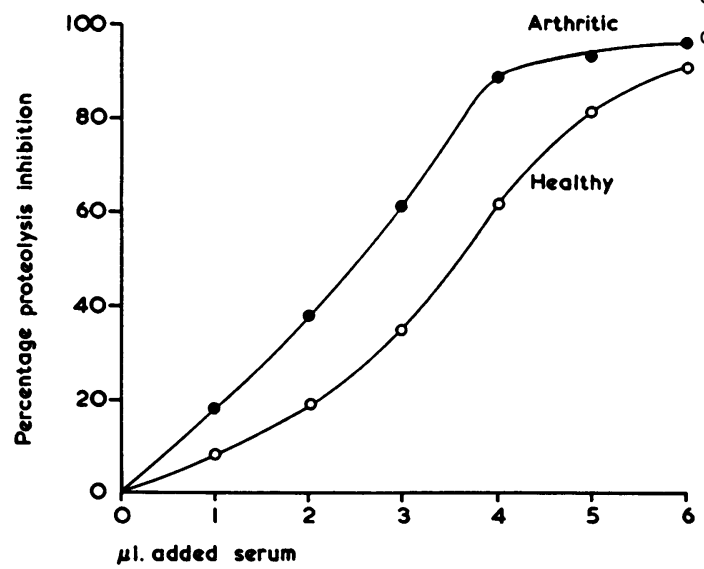

Fig. 2.-Relationship between amount of serum added to elastasecasein system and percentage of proteolysis inhibition.

Inhibition of the proteolytic function of trypsin. 0.07 ml. serum diluted $1: 10$ with $0 \cdot 1 \mathrm{M}$ sodium phosphate buffer $p \mathrm{H} 7.6$ and $40 \mu \mathrm{g}$. trypsin in $0.93 \mathrm{ml}$. of the same buffer were mixed and incubated for $10 \mathrm{~min}$. at $35^{\circ} \mathrm{C}$. The further procedure was exactly the same as described for inhibition of proteolysis of elastase. The Ac-value was equal to $0.85 \pm 0.01 \mathrm{mg}$. of TCA-soluble material. The results of the experiment, on the basis of which the 
amount of serum used for determination was chosen, are presented in Fig. 3, which shows the proper amount of serum tested is $7 \mu$.

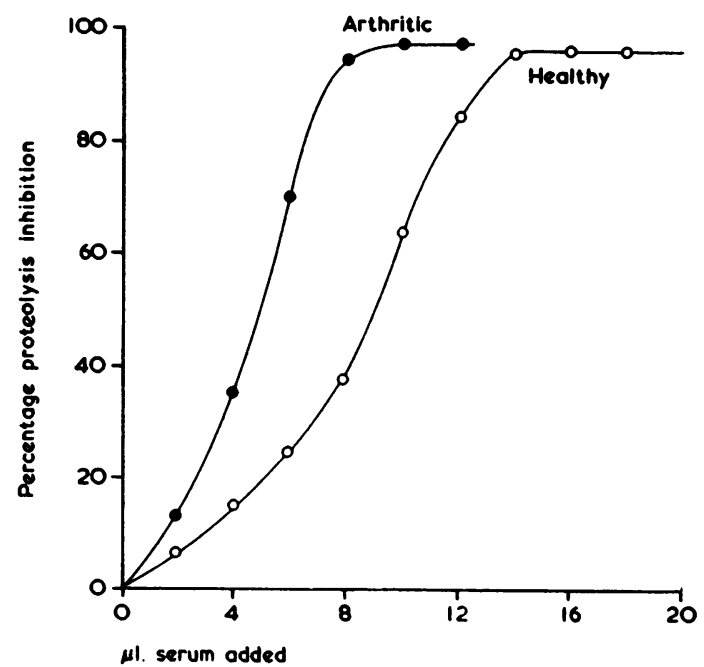

Fig. 3.- Relationship between amount of serum added to trypsincasein system and percentage of proteolysis inhibition.

Inhibition of the proteolytic function of plasmin. 0.02 $\mathrm{ml}$. serum and $800 \mu \mathrm{g}$. of the enzyme in $0.98 \mathrm{ml}$. of 0.1 $M$ sodium phosphate buffer $p \mathrm{H} 7.6$ were mixed and incubated for $10 \mathrm{~min}$. at $38^{\circ} \mathrm{C}$. Thereafter $1 \mathrm{ml}$. of a 3 per cent. casein solution was added. The reaction was carried out for $120 \mathrm{~min}$. at $38^{\circ} \mathrm{C}$. without shaking. The further procedure was the same as described above for inhibition of proteolysis of elastase. The Ac-value was equal to $0.63 \pm 0.01 \mathrm{mg}$. of TCA-soluble material. The volume of serum used for the determination, amounting to $20 \mu 1$., was chosen on the basis of experiment, the results of which are presented in Fig. 4.

\section{Results}

Fig. 5 shows inhibition of the elastolytic function of elastase by sera of healthy subjects and of patients with chronic rheumatic diseases.

Patients with RA and AS may be divided into two groups: those with only slightly increased levels of inhibitor in the serum, and those whose sera show high levels of inhibitor against the elastolytic function of elastase. The sera of only a limited number of patients exhibit an inhibition between 46 and 81 per cent. Most of the patients with AS belong to the second group.

When mean values for all results shown in columns $a, b$, and $c$ are calculated, a great increase of inhibitor activity is evident in the sera of patients with chronic rheumatic diseases, compared with those of

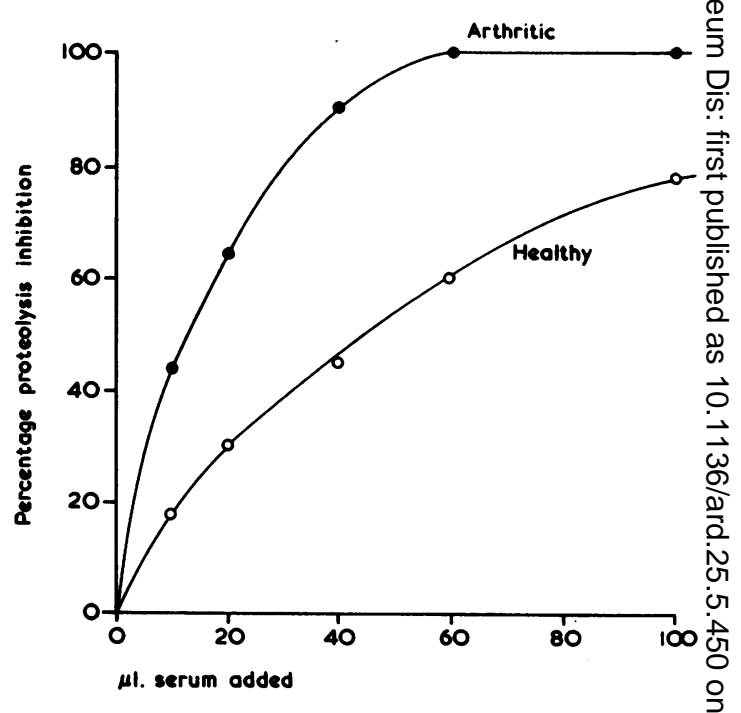

Fig. 4.-Relationship between amount of serum added to plasmin casein system and percentage of proteolysis inhibition.

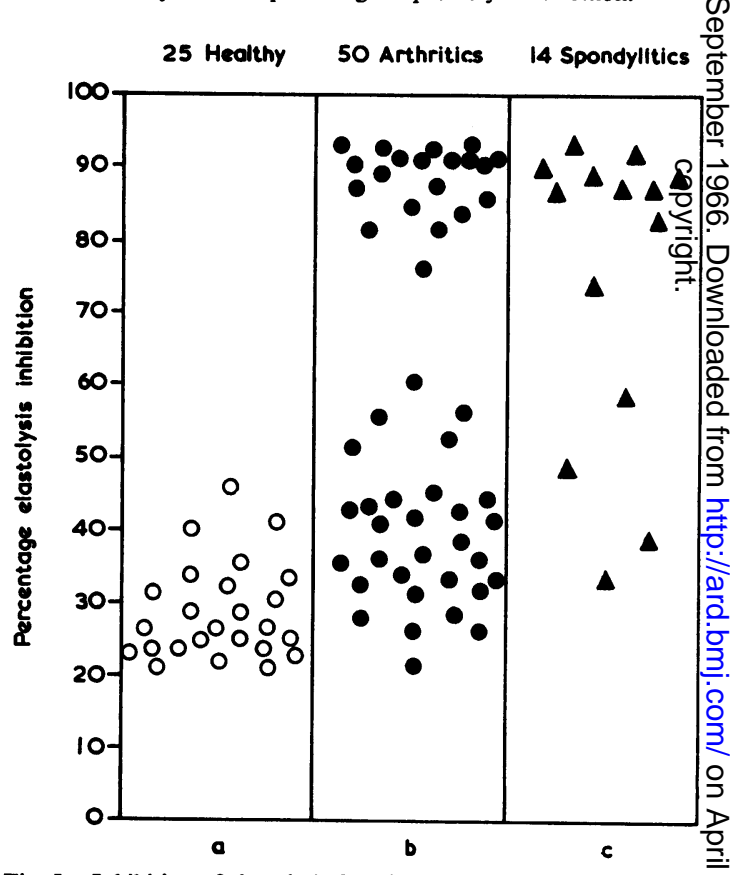

Fig. 5.-Inhibition of elastolytic function of elastase by sera of (a) $25 \mathrm{~N}$ healthy subjects, (b) fifty patients with rheumatoid arthritis, and $(c) \mathrm{U}$ fourteen patients with ankylosing spondylitis.

normal subjects. Moreover, the activity of the inhibitor in sera of patients with AS was greater than that in sera of patients with RA (Table I, opposite)

Fig. 6 (opposite) shows inhibition of the proteolytic function of elastase. The sera of patients with RA $\stackrel{\text { ? }}{+}$ 
TABLE I

MEAN VALUES OF INHIBITOR ACTIVITY (PER CENT.) IN SERA OF NORMAL SUBJECTS, CASES OF RHEUMATOID ARTHRITIS, AND CASES OF ANKYLOSING SPONDYLITIS

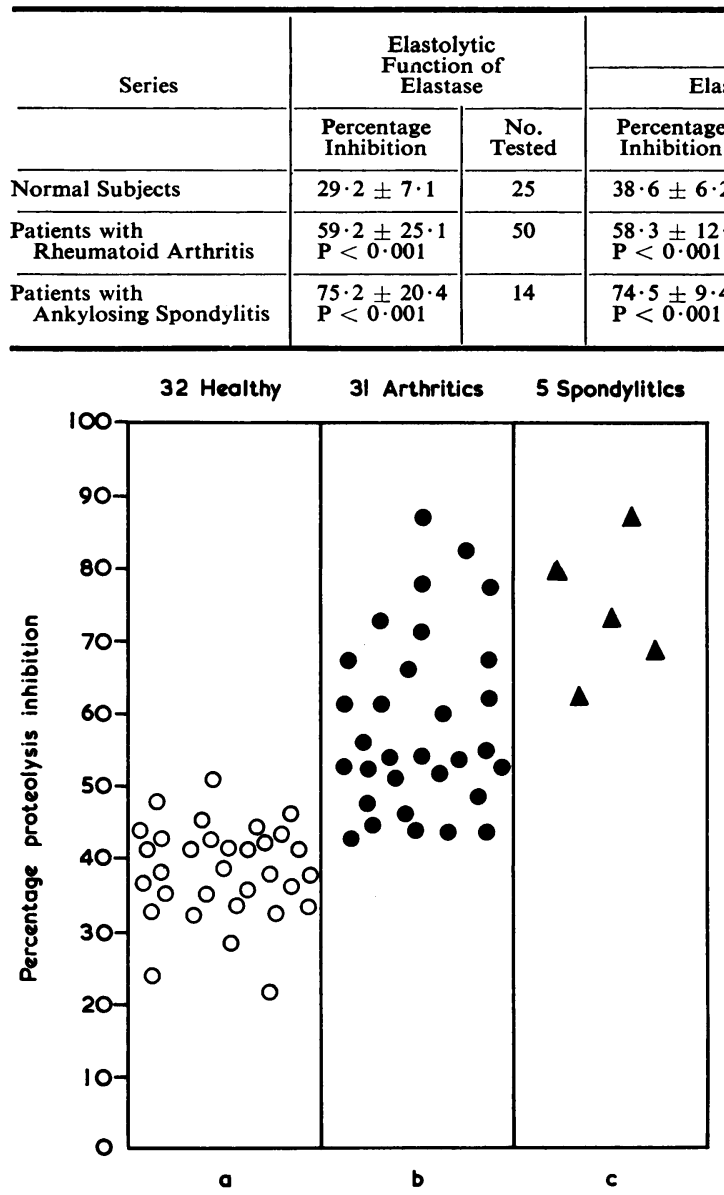

Fig. 6.-Inhibition of proteolytic function of elastase by sera of $(a) 32$ healthy subjects, (b) 31 patients with rheumatoid arthritis, and (c) five patients with ankylosing spondylitis.

and AS show uniformly distributed results. The mean values (shown in columns $a, b$, and $c$ ) indicate that the activity of the inhibitor of the proteolytic function of elastase is enhanced in all rheumatoid patients but is somewhat higher in those with AS (Table I).

Fig. 7 shows inhibition of the proteolytic function of trypsin by normal and pathological sera. Increase of inhibitor activity is clearly visible for patients with AS and RA; it also is higher in cases of AS (see Table I).

Fig. 8 (overleaf) shows inhibition of the proteolytic function of plasmin; the inhibitor activity is again increased, but there is little difference between the two groups with rheumatic disease.
Proteolytic Function of

\begin{tabular}{|c|c|c|c|c|}
\hline lastase & \multicolumn{2}{|c|}{ Trypsin } & \multicolumn{2}{|c|}{ Plasmin } \\
\hline $\begin{array}{l}\text { No. } \\
\text { Tested }\end{array}$ & $\begin{array}{l}\text { Percentage } \\
\text { Inhibition }\end{array}$ & $\begin{array}{l}\text { No. } \\
\text { Tested }\end{array}$ & $\begin{array}{l}\text { Percentage } \\
\text { Inhibition }\end{array}$ & $\begin{array}{l}\text { No. } \\
\text { Tested }\end{array}$ \\
\hline 32 & $30 \cdot 8 \pm 4 \cdot 6$ & 32 & $34 \cdot 1 \pm 8 \cdot 2$ & 26 \\
\hline $2 \cdot 1$ & $\begin{array}{l}52 \cdot 3 \pm 19 \cdot 0 \\
P<0.001\end{array}$ & 31 & $\begin{array}{l}64 \cdot 1 \pm 15 \cdot 7 \\
P<0 \cdot 001\end{array}$ & 27 \\
\hline 5 & $\begin{array}{l}80 \cdot 1 \pm 15 \cdot 3 \\
P<0.001\end{array}$ & 5 & $\begin{array}{l}63.8 \pm 13 \cdot 8 \\
P<0.001\end{array}$ & 4 \\
\hline
\end{tabular}

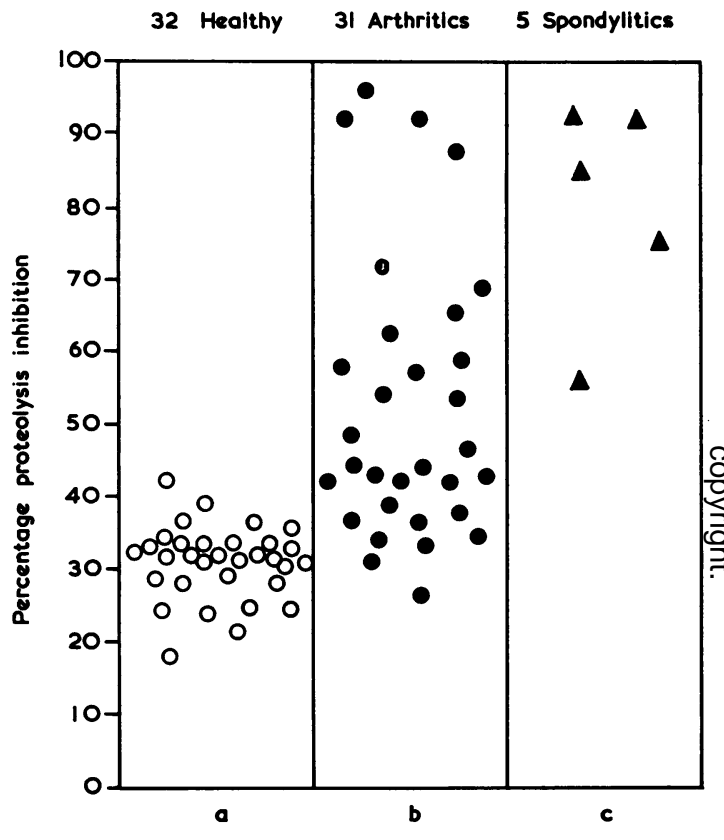

Fig. 7.-Inhibition of proteolytic function of trypsin by sera of $(a) 32$ healthy subjects, (b) 31 patients with rheumatoid arthritis, and (c) five patients with ankylosing spondylitis.

Mean values of inhibitor activity against all the enzymes tested are assembled in Table $I$.

The differences between inhibitor levels in both rheumatic diseases and in the control group are all statistically significant $(P<0.001)$.

Table II (overleaf) demonstrates inhibitor activity in sixteen selected sera against four enzymatic functions. In patients with RA the activity of all the inhibitors increases simultaneously, except that plasmin inhibitor activity oscillates around one relatively high value independently of the others. In patients with AS, the high activity of all the inhibitors changes simultaneously. The inhibitor of the elastolytic function of elastase was very active in all these patients. 


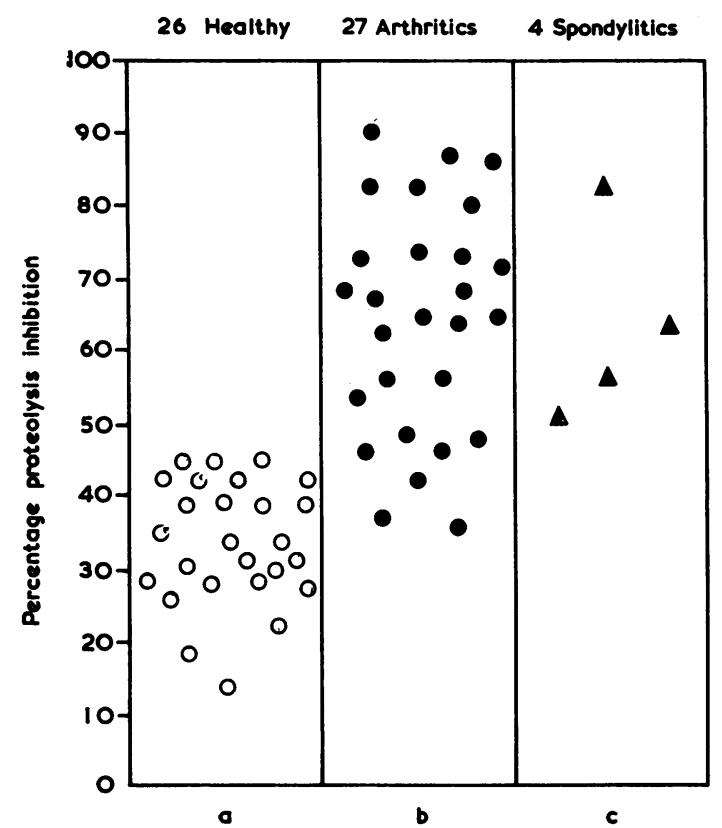

Fig. 8. - Inhibition of proteolytic function of plasmin by sera of (a) 26 healthy subjects, (b) 27 patients with rheumatoid arthritis, and (c) four patients with ankylosing spondylitis.

TABLE II

COMPARISON OF INHIBITOR ACTIVITY (PER CENT.) IN SERA OF TWELVE PATIENTS WITH RHEUMATOID ARTH RITIS (ARRANGED IN ASCENDING ORDER OF ELASTOLYTIC FUNCTION OF ELASTASE) AND IN FOUR PATIENTS LYTIC FUNCTION OF ELASTASE) AND IN FOUR PATIENTS
WITH ANKYLOSING SPONDYLITIS (ARRANGED IN ASCENDING ORDER OF PROTEOLYTIC FUNCTION OF ELASTASE)

\begin{tabular}{|c|c|c|c|c|}
\hline \multirow[t]{2}{*}{ Series } & \multirow{2}{*}{$\begin{array}{c}\text { Elastolytic } \\
\text { Function } \\
\text { of } \\
\text { Elastase }\end{array}$} & \multicolumn{3}{|c|}{ Proteolytic Function of } \\
\hline & & Elastase & Trypsin & Plasmin \\
\hline $\begin{array}{l}\text { Patients } \\
\text { with } \\
\text { Rheumatoid } \\
\text { Arthritis }\end{array}$ & $\begin{array}{l}21 \cdot 6 \\
26 \cdot 4 \\
27 \cdot 2 \\
28 \cdot 8 \\
41 \cdot 0 \\
45 \cdot 6 \\
76 \cdot 8 \\
82 \cdot 4 \\
91 \cdot 2 \\
91 \cdot 2 \\
92 \cdot 0 \\
92 \cdot 8\end{array}$ & $\begin{array}{l}43 \cdot 8 \\
43 \cdot 8 \\
48 \cdot 0 \\
42 \cdot 3 \\
52 \cdot 6 \\
54 \cdot 1 \\
55 \cdot 7 \\
65 \cdot 7 \\
66 \cdot 0 \\
83 \cdot 0 \\
77 \cdot 8 \\
77 \cdot 8\end{array}$ & $\begin{array}{l}25 \cdot 9 \\
37 \cdot 2 \\
41 \cdot 9 \\
36 \cdot 6 \\
44 \cdot 6 \\
46 \cdot 5 \\
57 \cdot 0 \\
43 \cdot 5 \\
58 \cdot 1 \\
96 \cdot 5 \\
68 \cdot 8 \\
91 \cdot 8\end{array}$ & $\begin{array}{l}65 \cdot 1 \\
62 \cdot 4 \\
69 \cdot 0 \\
73 \cdot 2 \\
46 \cdot 5 \\
48 \cdot 9 \\
69 \cdot 0 \\
67 \cdot 6 \\
68 \cdot 4 \\
83 \cdot 2 \\
65 \cdot 1 \\
71 \cdot 6\end{array}$ \\
\hline $\begin{array}{l}\text { Patients } \\
\text { with } \\
\text { Ankylosing } \\
\text { Spondylitis }\end{array}$ & $\begin{array}{l}88 \cdot 0 \\
84 \cdot 6 \\
93 \cdot 6 \\
90 \cdot 4\end{array}$ & $\begin{array}{l}62 \cdot 8 \\
69 \cdot 1 \\
73 \cdot 7 \\
80 \cdot 0\end{array}$ & $\begin{array}{l}55 \cdot 8 \\
75 \cdot 0 \\
84 \cdot 9 \\
92 \cdot 3\end{array}$ & $\begin{array}{l}51 \cdot 4 \\
56 \cdot 8 \\
64 \cdot 0 \\
83 \cdot 0\end{array}$ \\
\hline
\end{tabular}

\section{Discussion}

The data here presented indicate that a marked increase of inhibitors of some proteolytic enzymes occurs in the sera of patients suffering from chronic rheumatic diseases. This increase occurs in general for all the enzyme functions tested. Table I shows that the elastolytic function of elastase, the proteolytic function of the same enzyme and the proteolytic $\exists$ function of trypsin are inhibited to a similar extent음. by sera of patients with RA; the same is true of? patients with AS, but the activity of the inhibitors is higher. It is therefore possible that the specifico inhibitors against these enzymatic functions could be synthesized or released approximately at the samen rate from the same site in the organism. Serum $\overrightarrow{0}$ inhibitor of plasmin, however, differs from the other inhibitors, being nearly the same in patients with $^{\text {s }}$ RA as in those with AS.

This different behaviour of plasmin inhibitor is $\vec{\omega}$ perhaps better demonstrated in Table II. Anothero mechanism may be involved in the appearance of an increased amount of plasmin in rheumatic diseases, as compared with the other inhibitors tested. This mechanism may be related to the presence of a plas - minogen-like substance in human organs rich inc connective tissue. As suggested by Kowalski,o Kopeć, Latallo, Roszkowski, and Sendys (1958), this plasminogen-like substance may be of signific-cs ance in the pathogenesis of connective tissue dis $\frac{\mathbb{D}}{0}$ orders such as RA.

In this work no systematic observations were madeo of the correlation between the activity of inhibitors in serum and the clinical state of the patients. Never-e theless, in some cases, an increase of inflammations appeared to be accompanied by an increase 9 in inhibitory activity, particularly that of the elastases inhibitor. The degree of articular change did not seem to be so correlated.

It is tempting to speculate that in chronic rheu- $\frac{D}{8}$ matic diseases a common mechanism causes the increase of proteolytic enzyme inhibitors, which mays arise as a response to an increased activity of proteo-lytic enzymes. Although we have so far no directo evidence for this, some experimental data favour such an assumption. It has been found that lysosomeso are more labile in connective tissue diseases than ine healthy subjects (Dingle, 1961; Weissman, 1964), and their disruption may release hydrolytic enzymeso which are involved in connective tissue injury? Activation of lysosomes may, in turn, be the resulf of antigen-antibody reaction (Weiss and Dingle $D$ 1964). It may be suggested that the local produc을 tion of degradative enzymes derived from lysosomesn may be neutralized in situ by specific inhibitors:" The consumption of the inhibitors may then stimu late their overproduction, so that the increased level can be regarded as a defence mechanism againsto hydrolytic enzymes either released from lysosomeso or formed by activation of pre-existing pro-enzyme इू by lysosome enzymes. 


\section{Summary}

Activity of inhibitors of the elastolytic and proteolytic functions of elastase, as well as of the proteolytic functions of trypsin and plasmin, were determined in sera of healthy subjects and of patients with rheumatoid arthritis and ankylosing spondylitis. A considerable increase in the inhibitors tested was found in the patients with rheumatic disease. In cases of ankylosing spondylitis the levels of inhibitors of both the functions of elastase and of the proteolytic function of trypsin were markedly higher than in cases of rheumatoid arthritis. In both groups of patients the inhibitor activity of the proteolytic function of plasmin was raised to about the same level. These findings indicate a simultaneous formation and accumulation of all the inhibitors tested in cases of chronic rheumatic disease.

The results are discussed from the point of view of the possible role of proteolysis in the pathogenesis of rheumatic diseases.

We wish to express our thanks to Prof. E. Kowalski for helpful discussion of this subject.

\section{REFERENCES}

Ardelt, W., Niedzwiecka-Namyslowska, I., Loegler. Z., Ksiezny, S., and Budzynski, A. Z. (1966). Reumatologia, 4, 1 .

Bagdy, D., and Banga, I. B. (1957). Acta physiol. Acad. Sci. Hung., 11, 371.

Balo, J. (1962). In "Aging around the World: Proc. 5th Congr. Int. Ass. Gerontol., San Francisco, 1960", p. 357.

—_ and Banga, I. (1949). Nature (Lond.), 164, 491. -(1953). Acta physiol. Acad. Sci. Hung., 4, 187.

Banga, I. (1963). Ibid., 24, 1.

Carter, P. K., and Walford, R. L. (1963). Ann. rheum. Dis., 22, 198.

Coke, H. (1949). Ibid., 8, 135.

Dingle, J. T. (1961). Proc. roy. Soc. Med., 55, 109.

Gilfillan, R. F., Sbarra, A. J., and Bardawil, W. A. (1961). Fed. Proc., 20, 161.

Hall, D. A., Keech, M. K., Reed, R., Saxl, H., Tunbridge, R. E., and Wood, M. J. (1955). J. Gerontol., 10, 388.

Kline, D. L. (1953). J. biol. Chem., 204, 949.

Kopec, M., and Amatuni, H. (1961). Pol. Tyg. Lek., 16, 1301.

Kowalski, E., Kopec, M., Latallo, Z., Roszkowski, S., and Sendys, N. (1958). Blood, 13, 436.

Laskowski, M. (1955). In "Methods in Enzymology", vol. 2, pp. 32-34, ed. S. P. Colowick and N. O. Kaplan. Academic Press, New York.

Partridge, S. M., Davis, H. F., and Adair, G. S. (1955). Biochem. J., 61, 11.
Ragan, C., Grokoest, A. W., and Boots, R. H. (1949). Amer.J. Med., 7, 741.

Schneider, R. B., Walford, R. L., and Dignam, W. J. (1960). J. appl. Physiol., 15, 992.

Thomas, D. P. P., and Dingle, J. T. (1955). Ann. rheum. Dis., 14, 195.

Walford, R. L., and Schneider, R. B. (1959). Proc. soc. exp. Biol. (N.Y.), 101, 31.

Weiss, L., and Dingle, J. T. (1964). Ann. rheum. Dis., 23, 57.

Weissman, G. (1964). Lancet, 26, 1373.

Inhibiteurs sériques de l'élastase, de la trypsine et de la plasmine dans les maladies rhumatismales chroniques

\section{RÉSUMÉ}

L'activité des inhibiteurs des fonctions élastolytique et protéolytique de l'élastase ainsi que de la fonction protéolytique de la trypsine et de la plasmine fut déterminée dans les sérums des sujets sains et des malades atteints d'arthrite rhumatismale et de spondylarthrite ankylosante. Une augmentation considérable des inhibiteurs étudiés fut trouvée chez des sujets atteints de maladie rhumatismale. Dans les cas de spondylarthrite ankylosante les taux des inhibiteurs des deux fonctions de l'élastase et de la fonction protéolytique de la trypsine furent netiement plus élevés que dans les cas d'arthrite rhumatismale. Dans les deux groupes de malades l'activité inhibitrice de la fonction protéolytique de la plasmine fut élevée à un niveau assez semblable. Ce résultats indiquent une formation et accumulatio simultanée de tous les inhibiteurs étudiés dans des cas de maladie rhumatismale chronique.

On discute ces résultats du point de vue du rôle possible de la protéolyse dans la pathogénie des maladies rhumatismales.

Inhibidores séricos de la elastasa, de la tripsina y de la plasmina en las enfermedades reumáticas crónicas

\section{Sumario}

La actividad de los inhibidores de las funciones elastolítica y protelítica de la elastasa así como de la función proteolítica de la tripsina y de la plasmina fué determinada en sueros de sujetos sanos y de enfermos con artritis reumatoide y espondilartritis anquilosante. Una aumentación considerable de los inhibidores estudiados fué encontrada en pacientes con enfermedad reumática. En los casos de espondilartritis anquilosante las cifras de los inhibidores de ambas funciones de la elastasa y de la función proteolítica de la tripsina fueron marcadamente. mayores que en los casos de artritis reumatoide. En N ambos grupos de enfermos la actividad inhibidora de la función proteolítica de la plasmina fué alta a un nivel aproximadamente igual. Estos resultados indican una formación y acumulación simultánea de todos los in- 0 hibidores estudiados en los casos de enfermedad reumática crónica.

Se discuten estos resultados desde el punto de vista del

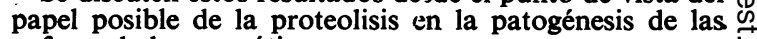
enfermedades reumáticas. 